\title{
Factors Influencing Rice Farmers' Risk Attitudes and Perceptions in Bangladesh amid Environmental and Climatic Issues
}

\author{
Md Din Il Islam, Airin Rahman², Md Nazirul Islam Sarker ${ }^{3 *}$, \\ Md Sazzadur Rahman Sarker ${ }^{4}$, Luo Jianchao ${ }^{1 * *}$ \\ ${ }^{1}$ College of Economics and Management, Northwest A\&F University, Yangling, China \\ ${ }^{2}$ Department of Agribusiness and Marketing, Sher-e-Bangla Agricultural University, Dhaka-1207, Bangladesh \\ ${ }^{3}$ School of Political Science and Public Administration, Neijiang Normal University, Neijaing, China \\ ${ }^{4}$ Krishi Gobeshona Foundation (KGF), BARC Campus, Dhaka, Bangladesh
}

Received: 14 February 2020

Accepted: 9 April 2020

\begin{abstract}
Rice farmers in Bangladesh face various environmental, climatic and market price-related risks. Choices of various operational tactics used for farm management are mostly influenced by farmers' risk perception and attitude. This study intends to discover the influencing factors of a farmer on the risk associated with environmental and climatic issues. This study quantifies the risk perceptions of rice farmers, their perceived behavior, and various associated underlying factors using a crosssectional dataset on 600 rice farmers from three major rice-growing districts in Bangladesh. Equally, Likely Certainty Equivalent approach has been used to rank the farmers' perceptions of three major risk dimensions such as the risk of market price fluctuation, the risk from various natural hazards, and risk of pest and disease. Probit regression is also used to discern the underlying factors affecting risk attitudes and perceptions. The results show that farmers' age, total family income, distance from the farm gate to the main market, savings, agricultural credit, off-farm income, access to information, and frequent contact with extension officers are significant determinants that affect farmers' risk attitudes and perceptions. This study provides in-depth insights for farmers, extension service providers, and agricultural planners on the real situation of farmers in developing countries, particularly those where crop insurance is still uncommon.
\end{abstract}

Keywords: agricultural credit, market risk, climatic risk, biological risk, off-farm income, rice cultivation, disaster management

\footnotetext{
*e-mail: sarker.scu@yahoo.com

**e-mail: jianchaoluo2015@gmail.com
} 


\section{Introduction}

Farmers constantly face an extensive series of risks because of variables such as the natural environment, market fluctuations, socio-political and policy fluctuations, and the biophysical environment [1]. Farmers should invest time and money for developing appropriate measures to avoid risks [2]. Such investments have greater return potentials but, at the same time, have a higher likelihood of failure [3]. Farming risks are increasing largely due to climate discrepancies, crop disease, variable agricultural product market prices [4], natural catastrophes, imperfect input and output markets [5], absence of financial facilities, and inadequate tactics to manage risk such as credit and/or crop insurance [6]. Farming is the major revenue source by which farm households identify and overcome the associated risks [7].

Agricultural risk is a complex problem not only for farm households that are forced to contend with but also the whole society that must play a role due to its effect on the economic sector [8]. Farmers can make a better decision related to crop management including assuming adaptive measures if they have a well understanding of the risk sources [9]. Agricultural risk is also important for society and agricultural policy makers who should understand farmers' risk perceptions to analyze farmers' decisions in such conditions [10]. Rice is the uppermost yielding cereal crop and main food in Bangladesh. Total rice production constitutes by three major rice crops (Aus, Aman, and Boro) in three different seasons of which Boro rice accounts for the principal share of overall rice production in Bangladesh. Rice farming faces continuous risks and uncertainties such as high cost and low return along with losses from disease, storms, and heavy winds. Bangladeshi farmers also face new and different adverse climatic conditions including salinity, low soil fertility, drought, and extreme temperature pressure [11]. All the climatic challenges increase the cost of irrigation, pesticides, and insecticides as well as the demand for timely supply of high-quality seed, which is more expensive and compounds the damage to total production. Additionally, rice blast fungi generally attack in harvesting season that may be a major risk of production loss. The lack of government supported programs such as input subsidies and output market stabilization, quality seed in hand and in time, crop insurance and credit facilities are other major sources of risk for rice growers [12].

Farmers' choices in circumstances, like risk and uncertainties can be investigated by considering their perception of risk and behavior toward the raised situation. Previous studies based on influencing factors for farmers risk perceptions and risk attitudes conducted in other countries failed to reach any concrete conclusion but showed mixed results instead [13-24]. In Bangladesh, this issue is very important due to a huge dependence of farmers on rice production, but it fails to get proper attention from the previous studies $[10,25$, 26]. A number of studies conducted on other countries have shown that risk preferences are differentiated based on age [3, 27, 28], education [26], family income [13] and farming experience [25]. Some researchers also consider access to climate information to be of great importance to the management of agricultural risk [20, 29].

Risk management system represents a challenge for such academics, researchers and development planners who have a lack of knowledge on farmers' attitudes towards risk mitigation $[3,30]$. It is important to understand risk information at the local farm level before developing an effective policy to assist farmers. Rice farming continues to face risks from various sources. Farmers could become discouraged by the sluggish growth in rice production despite it being a major crop in Bangladesh. Indeed, rice production rates in Bangladesh have slowed down from an usual of about 5\% per year during fiscal year (FY) 20072011 to a little over 2\% per year in FY 2012-2016 [31]. Nonetheless, rice continues to hold the leading position in total agricultural growth. While rice production has more than tripled since liberation, the progress has pitifully paled. The national average real price of rice fell by more than $50 \%$ over the past 35 years, with actual prices peaking in 2008 and 2009 (Fig. 1). An overwhelmingly unanimous opinion is that, despite the Bangladesh Rice Research Institute (BRRI) developing over 100 rice varieties, the acceptance rate has remained persistently low.

Consequently, the significance to explore the farmers' risk perceptions and risk attitudes related to rice farming is unquestionable. The findings of the present study may explain what perceptions and attitudes ultimately shape farmers' decisions under risky situations and may assist the policy makers in developing comprehensive policies for farmer adoption.

Bangladesh is a middle-income country that has been moving toward industrialization in recent times. Bangladeshi farmers face challenges in the form of both man-made and natural calamities. Moreover, the farmers' vulnerabilities have not been addressed

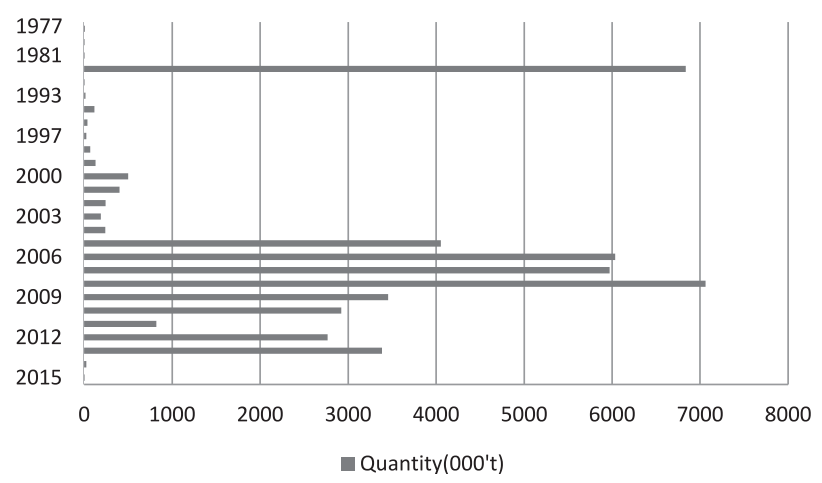

Fig. 1. Rice export trends in Bangladesh (1977-2015).

Source: Bangladesh government export-import rice data resource. 
properly at the national policy level. In recent years, some rice farmers in Bangladesh have adopted offfarm income diversification and agricultural credit as risk management tools [32]. These strategies depend on certain underlying socioeconomic factors related to farm and farm households. In this present study, we also examine the influential factors that affect farmers' decisions to adopt risk-averse alternatives. This study's novelty lies in examining a relatively unexplored area: the factors affecting farmers' simultaneous implementation of risk managing tools to overcome the risks associated with rice production. Diversification of activities (e.g., farming two types of crops or undertaking two different investments) is an effective risk management strategy because not all activities react the same way to events that occur at a specific time [5]. Agricultural credit significantly affects farmers' income, production, and food security, particularly in areas where farmers are vulnerable to floods, pest disease, environmental degradation, and other catastrophic hazards [32]. The findings of this study will guide governments in shaping policy initiatives designed to help farmers who are suffering from high production cost and low profit due to natural hazards, environmental degradation from industrialization, and other catastrophic hazards [33].

\section{Data and Methods}

\section{Geographical Features of the Study Area}

Three major rice producing areas in Bangladesh selected for this study such as Mymensingh, Barisal, and Comilla district (Fig. 2). Rice producers are available in almost all areas in Bangladesh. We, however, chose these areas because of their huge production qualities of the three varieties of rice like Aus, Aman, and Boro. The other advantage of selecting these areas is to obtain a clear picture of the risk factors to rice farmers who have already faced climate change effects. The selected areas provide information about all the variations in environmental and socio-economic condition, and exposure to various types of risks. The average annual rainfall in these areas is approximately $2,320 \mathrm{~mm}$. Summer temperature varies during the period of April and May from the range of $35^{\circ} \mathrm{C}$ to $41^{\circ} \mathrm{C}$. December and February are comparatively cooler months and day time

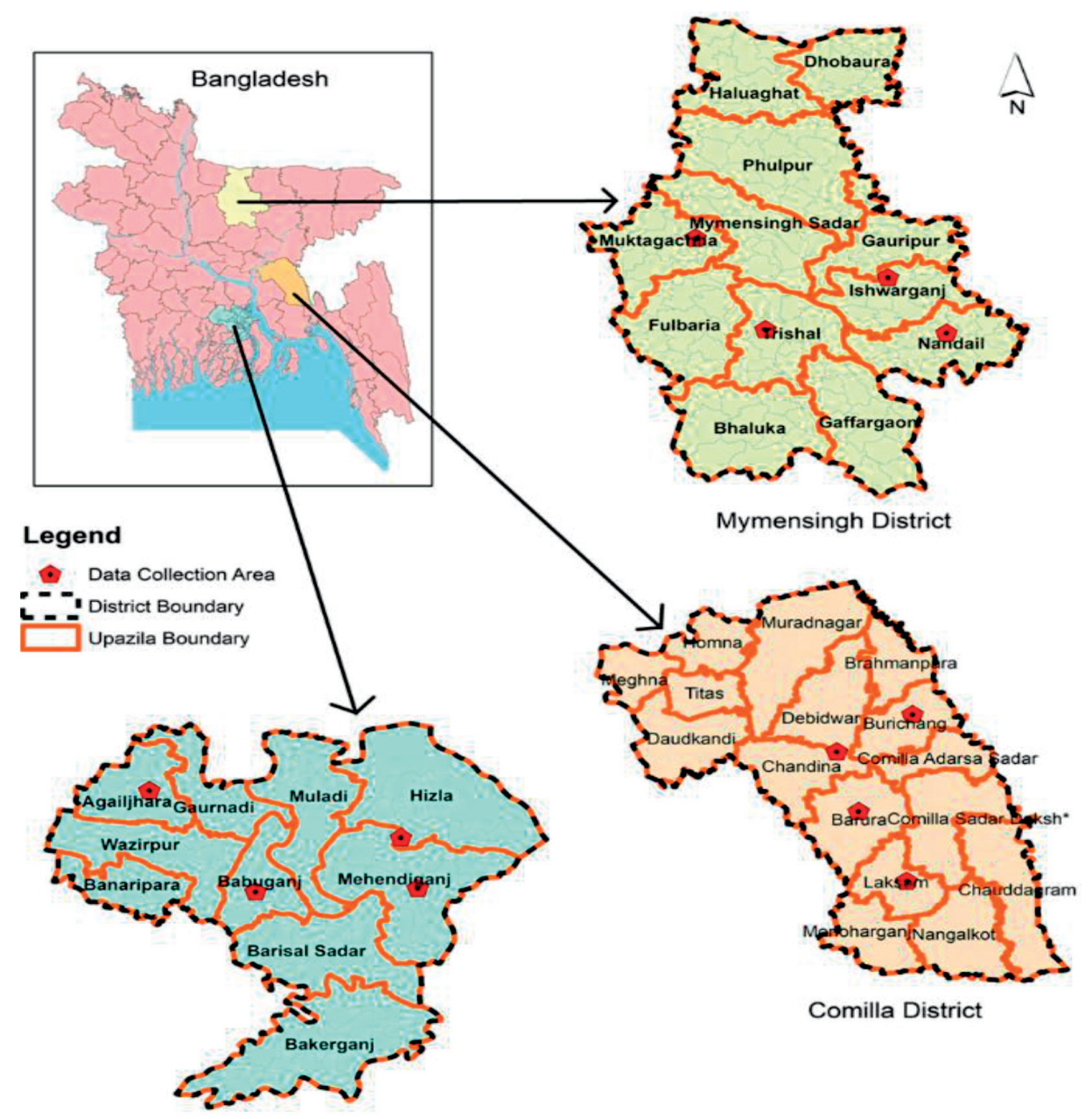

Barisal District

Fig. 2. Study areas in Bangladesh. 
temperatures approximately vary between 15 to $20^{\circ} \mathrm{C}$ and it is ranges $10^{\circ} \mathrm{C}$ and below at night time [34]. The study areas have two main seasons like Rabi (November to April) and Kharif (May to October). Primary data for this study were collected from January to March 2019 from these three different agro-ecological regions in Bangladesh. In some years, an early monsoon creates excessive rainfall in these areas, this unwanted rainfall may harm the growth of new seedlings, and again the delay of the start of a monsoon creates severe water stress and increases the cost of irrigation. The saline soils are mostly unfertile in these areas which increases the cost of fertilizers and manures.

\section{Sampling and Data Collection}

For this study, selection of study area and farm families were done by using multi-stage random sampling method. Firstly, we selected greater Mymensingh, greater Barisal, and greater Comilla zone based on the high density of rice farmers in these areas. In the second step, we randomly selected three districts: Mymensingh, Barisal, and Comilla. Next, in the third step, we used a random sampling technique to select four upazilla (local administrative unit lower than district but upper than village level) from those districts. In the final stage, we randomly selected farm households from the list provided by the Upazilla Council Office. We surveyed 50 rice growers from each village and used the following equation developed by Yamane [35] and also used by others [36, 37] (Eq. 1):

$$
n=\frac{N}{1+N e^{2}}
$$

...where, $\mathrm{n}$ is the sample size in each area and $\mathrm{N}$ is the number of agricultural debtor households in an area, representing a precision set at $15 \%(0.15)$.

A structured questionnaire was used to collect data from farm households (Appendix A). The survey questionnaire included all the related information concerning farm and farm household characteristics, income sources, savings information, farmer perceptions of the different risk sources for rice farming, farmers' risk attitudes and respective risk perception indicators. An oral approval was taken from the respondent before face to face interview. Besides, all ethical issues were followed during interview with the respondents.

\section{Risk Perception}

Farmers actually showed their perception about the severity and frequency of risk sources by giving score of each risk source (market, climatic, biological, and financial risk) by following Likert scale method. In our used Likert scale, the risk sources were scored from 1 (very low) to 5 (very high). Farmers made their on-score card that was based on their own experience and understanding of occurred risk situation in past years. Then, we calculated the risk factor by totaling the value and probability [38]. If the risk factor score is between 2 and 5 , then it is considered as low and if it is between 6 and 10 then considered as high. A high level is coded by 1 and 0 for otherwise.

\section{Risk Attitude}

To measure the farmers' risk attitude, we adopted the Equally Likely Certainty Equivalent (CE) method that was also adopted in some previous studies to measure farmers' production risk and catastrophic risk management strategies [21, 39, 40]. The technique for assessing this method comprises all risky consequences with discrete payoffs stated as $R_{1}, R_{2}, \ldots, R_{m}, \ldots, R_{n-1}, R_{n}$ with specific likelihoods of $P_{1}, P_{2}, \ldots, P_{m}, \ldots, P_{n-1}, P_{n}$, wherever the sum of all likelihoods is 1 . This process recognizes the preferences for finding a CE for a hypothetical 50/50 outcome with a favorable payoff $R_{\mathrm{n}}(\mathrm{U}=1)$ and unfavorable outcomes $R_{1}(\mathrm{U}=0)$. The method supposed that farmers may choose one outcome from probable two outcomes based on their hypothetical monetary values that make them indifferent amid two risky outcomes as total BDT 1 (total monthly household income about BDT 50,000) and BDT 0 with the same likelihood. For example, let BDT 25,000 as the CE of a farmer for the income level of BDT 50,000 and BDT 0 with equivalent likelihood, and this worth is greater than $R_{1}$ and less than $R_{n}$. Then, the anticipated utility for the CE of $R_{m}$ is calculated by means of the similar method $(\mathrm{U}=0.5)$, and the process continues until we attain adequate data facts. Using the above example, the equation (Eq. 2) to calculate the $\mathrm{CE}$ of the utility value with probability $(0.5)$ is

$$
\begin{gathered}
\mathrm{U}(25000)=0.5 \mathrm{u}(0)+0.5 \mathrm{u}(50000) \\
=0.5(0)+0.5(1)=0.50
\end{gathered}
$$

The CEs are then applied to a cubic utility function to attain the utility of each farm household as follows (Eq. 3):

$$
u(w)=\alpha_{1}+\alpha_{2} w+\alpha_{3} w^{2}+\alpha_{4} w^{3}
$$

Mathematical form for Absolute Risk aversion is as follows (Eq. 4):

$$
r_{a}(w)=-\frac{U^{\prime}(W)}{U^{\prime \prime}(W)}
$$

Here, the $1^{\text {st }}$ and $2^{\text {nd }}$ order indicators of wealth are denoted by $U^{\prime}$ and $U^{\prime \prime}$ respectively, and indicator of absolute risk aversion is $r(w)$. Positive and negative coefficient for absolute risk aversion presents the risk averse and risk prefer nature for respondents respectively. If respondents show unresponsiveness to risk then the result will be zero. Risk averse nature of the respondents will be equals to 1 and 0 otherwise. 


\section{Dependent and Independent Variables}

Based on the status of rice farming conditions in Bangladesh and considering the contemporary review of the relevant literatures we adopted farm and household characteristics such as age, education, rice farming experience, savings, off-farm income, contract farming, agricultural credit, family size, total monthly family income, distance from farm-gate to main market, access to update information, and frequent contact with extension officers as independent variables in this study. The dependent variables used in the study are risk attitudes and farmers perceptions of three types of risks: market risk (high input cost, low output price, low profit due to a long supply chain), climatic risk (drought, flood, heavy wind, precipitation) and biological risks (rice hopper attacks, rice blasts, weed infestation, and rodent attacks during the harvesting period).

\section{Probit Regression}

The dependent variables of this study having dichotomous nature that motivated the author to use
Probit model which is given as (Equation 5):

$$
Y_{i}=\propto+\sum X_{i} \beta+\varepsilon
$$

Here, $Y_{i}$ is the dependent variable (dichotomous) that shows the risk perceptions and risk -averse attitudes in this study. $X_{i}$ is the independent variable (socioeconomic characteristics of the farm and farming households) used in the analysis, $\beta$ is the vector of unidentified parameters (to be estimated), and $\varepsilon$ is the error term.

\section{Results and Discussion}

\section{Demography, Risk Perception and Attitude of Farmers}

The results of the demographic factors of farmers such as age, education, family size, experience, farm size, distance, saving, access to information and extension services with risk perception and attitude have been presented in Table 1.

Table 1. Descriptive analysis of the variables used in the model.

\begin{tabular}{|c|c|c|c|}
\hline Variables & Description & Mean & $\begin{array}{l}\text { Standard } \\
\text { Deviation }\end{array}$ \\
\hline \multicolumn{4}{|c|}{ Independent Variables } \\
\hline \multicolumn{4}{|c|}{ Households socio-economic characteristics } \\
\hline Age & Continuous & 41.105 & 6.980 \\
\hline Education (years) & Continuous & 6.233 & 3.200 \\
\hline Family Size & Continuous & 4.275 & .919 \\
\hline Experience (years) & Continuous & 8.460 & 3.295 \\
\hline Total Income (USD/month) & Continuous & 28007.167 & 7163.807 \\
\hline Farm Size & $\begin{array}{c}\text { Dummy takes the value } 1 \text { if small (farm size: }<6 \text { acres as small, } 6-10 \\
\text { acres as medium, and }>10 \text { acres as large) and } 0 \text { otherwise }\end{array}$ & 0.705 & 0.456 \\
\hline Distance $(\mathrm{km})$ & $\begin{array}{l}\text { Dummy takes the value } 1 \text { if short ( } 0-4 \mathrm{~km} \text { away from the main mar- } \\
\text { ket) and } 0(>4 \mathrm{~km} \text { away from main market) otherwise }\end{array}$ & 0.672 & .470 \\
\hline Savings & Dummy takes the value 1 if high and 0 otherwise & 0.913 & 0.282 \\
\hline Access to Information & Dummy takes the value 1 if there is access and 0 otherwise & 0.825 & 0.380 \\
\hline $\begin{array}{l}\text { Frequent contact with exten- } \\
\text { sion officers }\end{array}$ & Dummy takes the value 1 if there is high frequency and 0 otherwise & 0.820 & 0.385 \\
\hline \multicolumn{4}{|c|}{ Risk Perceptions } \\
\hline Market Risk (binary) & Dummy takes the value 1 if market risk value $>5$ and 0 otherwise & 0.798 & 0.402 \\
\hline Climatic Risk (binary) & Dummy takes the value 1 if climatic risk value $>5$ and 0 otherwise & 0.907 & 0.2911 \\
\hline Biological Risk (binary) & Dummy takes the value of 1 if biological risk value $>5$ and 0 otherwise & 0.732 & 0.444 \\
\hline Risk Attitude & Dummy takes the value 1 if risk averse and 0 otherwise & 0.843 & 0.364 \\
\hline \multicolumn{4}{|c|}{ Dependent Variables } \\
\hline Agricultural Credit & Dummy takes the value 1 if there is agricultural credit and 0 otherwise & 0.397 & 0.4896 \\
\hline Off-farm Income & Dummy takes the value 1 if there is off-farm income and 0 otherwise & 0.785 & 0.4112 \\
\hline
\end{tabular}

Source: Field survey 
The values in Table 1 show that the farmers in the study area are 41 years old on an average. Each farmer had an average of eight years of rice farming experience and an average of six years of total education. The majority $(71 \%)$ of the farmers had limited or small land size. Most of the respondents $(67 \%)$ had a farm located a short distant from the main market, and there was an average of four members in each family. In this study, majority of farmers $(84 \%)$ show a risk-averse attitude, that is, they are not willing to assume any type of risk. The result also reveals that climatic risk perceived as the most important risk by $91 \%$ farmers while $73 \%$ farmers perceive biological risk as the least important risk. Market risk $(80 \%)$ is also considered important by rice farmers. This condition parallels to the present situation of rice farming in Bangladesh. A higher cost of formal or informal credit makes it more difficult for poor and marginal farmers to have adequate financing for rice production. Again, even if farmers can manage their financing, there is no guarantee that turnover can cover their costs of production due to input or output market fluctuations and climatic variations (high rainfall, flood, temperature fluctuations, drought, hail storms) [41]. The risks from rice blasts and pest attacks are under control for many farmers because the government of Bangladesh provides a generous pesticide subsidy. However, many poor farmers are living in a distant place from the main markets and does not receive government provided subsidy that enhances their probability of huge biological risk.

\section{Factors Affecting Risk Attitudes}

The values of the model analysis regarding the influential factors for farmers' risk attitudes and risk perceptions have been presented in Table 2. The values

Table 2. Parameter estimation of the Probit model on factors affecting farmers' risk attitudes and perceptions.

\begin{tabular}{|c|c|c|c|c|}
\hline \multirow{2}{*}{ Explanatory Variables } & \multirow{2}{*}{ Risk Attitude } & \multicolumn{3}{|c|}{ Risk Perceptions } \\
\hline & & Market risk & Climatic Risk & Biological Risk \\
\hline Age & $\begin{array}{c}-0.0251 \\
(-0.0279)\end{array}$ & $\begin{array}{c}0.0870^{* * *} \\
(0.0163)\end{array}$ & $\begin{array}{l}-0.0112 \\
(0.0177)\end{array}$ & $\begin{array}{c}-0.0312 * * \\
(0.0147)\end{array}$ \\
\hline Education (Year) & $\begin{array}{c}0.0458 \\
(0.0436)\end{array}$ & $\begin{array}{c}0.0216 \\
(0.0231)\end{array}$ & $\begin{array}{l}-0.0046 \\
(0.0255)\end{array}$ & $\begin{array}{c}-0.0328 * \\
(0.0204)\end{array}$ \\
\hline Family Size & $\begin{array}{l}-0.1972 \\
(0.1441)\end{array}$ & $\begin{array}{l}-0.0452 \\
(0.0766)\end{array}$ & $\begin{array}{l}-0.0701 \\
(0.0894)\end{array}$ & $\begin{array}{c}0.1088 \\
(0.0739)\end{array}$ \\
\hline Experience (Year) & $\begin{array}{c}-0.0721 \\
(0.0751)\end{array}$ & $\begin{array}{c}0.0033 \\
(0.0364)\end{array}$ & $\begin{array}{c}0.0100 \\
(0.0370)\end{array}$ & $\begin{array}{c}-0.0640 * \\
(0.0287)\end{array}$ \\
\hline Total Income Month & $\begin{array}{l}-0.0001 \\
(0.00001\end{array}$ & $\begin{array}{c}0.0001^{* *} \\
(0.0000)\end{array}$ & $\begin{array}{c}0.0001 \\
(0.0001)\end{array}$ & $\begin{array}{c}0.0001 * * * \\
(0.0001)\end{array}$ \\
\hline Farm Size & $\begin{array}{c}0.2059 \\
(0.2716)\end{array}$ & $\begin{array}{l}0.2726^{*} \\
(0.1489)\end{array}$ & $\begin{array}{c}0.1223 \\
(0.1649)\end{array}$ & $\begin{array}{c}0.0866 \\
(0.1336)\end{array}$ \\
\hline Distance $(\mathrm{km})$ & $\begin{array}{c}-0.5634 \\
(0.4151)\end{array}$ & $\begin{array}{c}0.7326^{* * *} \\
(0.1941)\end{array}$ & $\begin{array}{c}-0.1472 \\
(0.2146)\end{array}$ & $\begin{array}{c}-0.1784 \\
(0.1869)\end{array}$ \\
\hline Savings & $\begin{array}{c}-1.2829^{* *} \\
(0.4196)\end{array}$ & $\begin{array}{c}-1.1802 * * * \\
(0.3040)\end{array}$ & $\begin{array}{c}-0.6172 \\
(0.4564)\end{array}$ & $\begin{array}{c}-0.4169 \\
(0.3141)\end{array}$ \\
\hline Agricultural Credit & $\begin{array}{c}-1.2850 * * * \\
(0.3571)\end{array}$ & $\begin{array}{c}0.5031^{* *} \\
(0.1694)\end{array}$ & $\begin{array}{c}-0.6356^{* * *} \\
(0.1739)\end{array}$ & $\begin{array}{c}0.7640 * * * \\
(0.1448)\end{array}$ \\
\hline Off-farm income & $\begin{array}{c}4.3735^{* * *} \\
(0.4179)\end{array}$ & $\begin{array}{c}0.1367 \\
(0.1969)\end{array}$ & $\begin{array}{c}0.0660 \\
(0.2071)\end{array}$ & $\begin{array}{c}0.9111^{* * *} \\
(0.1699)\end{array}$ \\
\hline Access to Information & $\begin{array}{c}1.4859 * * \\
(0.6172)\end{array}$ & $\begin{array}{l}-0.1009 \\
(0.3505)\end{array}$ & $\begin{array}{l}-0.1142 \\
(0.4072)\end{array}$ & $\begin{array}{l}-0.2541 \\
(0.3156)\end{array}$ \\
\hline Frequent contact with extension officers & $\begin{array}{l}-0.8214 \\
(0.6081\end{array}$ & $\begin{array}{c}-0.9521^{* *} \\
(0.3880)\end{array}$ & $\begin{array}{c}-0.1396 \\
(0.3922)\end{array}$ & $\begin{array}{c}-0.3617^{* *} \\
(0.1990)\end{array}$ \\
\hline Log Likelihood & -63.8 & -228.9 & -175.071 & -287.48 \\
\hline LR test $\operatorname{chi}^{2}(12)$ & 393.16 & 145.32 & 22.08 & 122.94 \\
\hline Pseudo-R ${ }^{2}$ & 0.7547 & 0.2409 & 0.059 & 0.1762 \\
\hline Prob $>$ chi $^{2}$ & 0.001 & 0.001 & 0.036 & 0.001 \\
\hline Number of observations & 600 & 600 & 600 & 600 \\
\hline
\end{tabular}

Note: Figures in parentheses are standard errors. *, **, and *** represent statistical significance at the $10 \%, 5 \%$, and $1 \%$ level respectively. 
indicate that savings and access to agricultural credit has a negative significant effect on risk attitudes, whereas off-farm income and access to information positively and significantly affects risk aversion attitudes. These results reflect the real situation for farmers. Farmers with more savings can afford credit expenses and always prefer risk rather than being risk averse. On the other hand, the farmers with greater access to information generally tend to be risk aversive and engage in offfarm income diversification [42]. Therefore, farmers who use off-farm income diversification as a risk management tool have substantial access to information exhibit more risk-averse behavior. For off-farm income, the result contradicts with Ullah and Shivakoti [43] and Akhtar et al. [3]. However, these studies were conducted on different crop sectors (hybrid maize) and in different countries due to cultural biases.

Major demographic characteristics of the respondents such as age, family size, total income per month, experience, distance, savings, agricultural credit, and access to an extension agent have a negative coefficient with risk-aversion. The consequences are consistent with previous studies conducted by Ullah et al. [43] and Akter et al. [36]. These findings are relevant to the Bangladesh context because farming represents a family business for many farmers who are choosing to continue their family concern for many years while assuming risk. Additionally, these farmers are habituated to the climatic and market conditions, and other factors influencing production and profit. Therefore, they are less concerned with these factors and prefer to take risk to obtain higher profits. The value of the analysis show that experience also shows a negative relationship with risk attitude which is consistent with the theory that older and highly experienced farmers always prefer risk and would seek opportunities rather than avoid risk. The results also reveal a new finding whereby a large family size has a positive relationship with risk preference because of access to labor gives farmers the confidence to assume more risk. The labor costs decrease with the increasing number of labor per household. This study emphasizes to the cost of labor due to its importance to poor farmers in a developing country like Bangladesh where farmers have less access to technologies to shift high labor costs.

The results of this study are unique in finding the relationship between total income per month and savings with risk attitude. Farmers who have substantial savings and high income can handle the risk because of having cash money. No previous studies have investigated these variables when considering risk attitudes and perceptions. The study finds out that the farmers who use agricultural credit can minimize risk. Farmers assume credit to fund some expenses; however, credit itself is a risk [10]. If growers do not attain targeted profit levels due to a climatic, biological or market risk, they may fall into credit default. Thus, farmers who use agricultural credit are less risk averse in nature. Again, the result shows an inverse relation between attitudes toward risk and access to extension agents. Access to extension agents enhances farmers' understanding of risk sources and risk management techniques. Farmers with greater access to extension contacts show less concern for risks and a preference to take risks [44]. Larger farmers in these study areas show a greater preference to take risks than small farmers. This is obvious that larger farmers have higher wealth compared to small holders and a greater capacity to take risks. The result of this study is in line with Akhter et al. [3].

\section{Factors Affecting Risk Perceptions}

This study also reveals mixed results concerning the impact of household socio-economic characteristics on farmers' perceptions (Table 2). Farmer age has a highly positive (at 1\% level of significance) influence on market risk and a negative influence (at 5\% level of significance) on biological risk. Older farmers consider the input-output price variation risk. Market risk is the most important risk factor that can bias their production decision, farm income, and profit margins [45]. Biological risk is also important in the case of young farmers with comparatively less farming, pest-handling, and insecticide experience [23].

This study also indicates that farmers with more experience and higher education emphasize that market risk is the most important factor whereas lessexperienced and less-educated farmers emphasize biological risk. On the other hand, total monthly income is positively correlated with each of the risk perceptions. Household characteristics has massive influence on market risk and biological risk perceptions. It indicates that farm households with higher incomes invest more in production to obtain greater profits. If the market fluctuation or a pest attack is beyond control, farm households suffer much more from a massive loss than households with less income. The rich farmers consider that climate is an important risk factor, but the result is not significant. Small-size farmers perceive that all the risk sources are major threats for their small farms. No other risk perceptions show any significant relation with farm size except for market risk (10\%). Moreover, distance from the farm-gate to major markets is strongly and positively affecting farmers' perceptions of market risk, while there is a negative correlation with climatic risk and biological risk. This is because of farmer's lack of access in remote areas to updated information on the pick time for input-output price, and farmers should consider the extra carrying cost for input-outputs from market to farm [46]. As a result, long-distant farmers perceive market risk to be a major threat for their farming business. On the other hand, farms are located in a long way from main markets. Farmers also have less access to extension agents and to updated information on climatic risk [47] and biological risk. Farmhouses with access to agricultural credit perceive market risk and biological risk to be major sources of 
risks [48]. These households rely on agricultural credit to manage high input costs such as quality seed, labor, irrigation, and insecticides and pesticides to avoid blast attacks and overcome the shocks from other diseases [9]. This study found unique results in the case of savings. Farm households with a comparatively large amount of savings have a negative correlation with all of the risk sources and a strong negative correlation with market risk perceptions. Farmers who have savings are not concerned with high input costs or fewer subsidies. They can manage all the necessities for better production independently and are not preoccupied with risk sources. Farm households with off-farm income show a higher perception concerning all the risk sources. This could be because higher risk perception encourages farmers to take advantage of off-farm income to compensate for the negative shocks from various types of risks and uncertainties [49]. Access to information to an extension agent lessens the risks from climatic disasters, biological factors, and market price fluctuations as farmers have easy access to updated information [50]. For the influence of extension agents, many farmers in Bangladesh understand the total production process and rice farming marketing system [24]. Consequently, farmers can take quick actions when necessary to mitigate their losses.

\section{Conclusion}

The findings of this study are based on rice growers in selected areas in Bangladesh and have broader inferences for agriculture based developing economies. It mainly intends to answer what influential factors affect farmers' decisions to adopt risk-averse alternatives. This research was conducted on three main rice-producing areas in Bangladesh where farmers use several means to manage the agricultural risks perceived from different risk sources. This study investigated many of the related farm and household characteristics and area-specific features affecting farmers' risk perceptions. The results revealed that most of the farmers are risk averse and are not able to minimize risk. Rice farmers' attitudes toward risk strongly influence their risk perceptions and risk management decisions. Farmers consider market price, biological, and climatic risks as the major risk sources for their rice farming in Mymensingh, Barisal, and Comilla divisions in Bangladesh. The analysis of this study explored that farmers' age, total family income, distance from farm-gate to major markets, savings, agricultural credit, off-farm income, access to information, and frequent contact with extension officers are significant determinants affecting farmers' risk attitudes and risk perceptions either positively or negatively. The evidence provided in this study will assist government in understanding the real situation concerning risk sources for agriculture and farmers' attitudes toward managing risk. It can lead to better policies and implementation to improve the sector's performance. Future research on the different risk sources for other crops or services in agriculture, agribusiness sector, and other broader areas could be encouraged.

\section{Acknowledgements}

This study is supported by "Research on the Pilot Effect Evaluation, Operational Pattern, Supporting Policies of the Contracted Management of Farmland Mortgage Finance" and the National Natural Science Foundation of China, Jan 2016-Dec 2019, grant no. 71573210. It is sponsored and hosted by Prof. Jianchao Luo.

\section{Conflict of Interest}

The authors declare no conflict of interest.

\section{Appendix A. Questionnaire of this study}

Information obtained from Farmers are kept confidential and not used for any purpose other than as database for our research on Risk management and adoption decision. Thank you for your cooperation.

Name of respondent: Age: Address:

Section One: Basic information about respondents' socio-economic status

(1) What is your education status?

(a) Not educated (b) less than primary (c) primary (d) secondary (e) higher secondary (f) above higher secondary

(g) technical education

(2) How many people are there in your household?

(3) How many are dependent on your income?

(4) Your annual farm income level (USD): (1) $\leq 2500$ (2) 2501-5000 (3) 5001-10000 (4) $\geq 10000$

(5) Your experience in years in rice farming:

(6) What is your savings status? (We assume more than 100USD/month means high savings) 
(a) I couldn't make any savings (b) I became indebt (c) I saved less than 60USD/month (d) I saved between 100USD

(e) I saved more than 100USD

(7) What is your farm size? Farm size:

[ $<6$ acres as small, $6-10$ acres as medium, and $>10$ acres as large]

(8) Distance from Major market: (1) 0-4 km [short distance] (2) above $4 \mathrm{~km}$ [long distance]

(9) Have you access update information on: (a) rice market price (b) weather forecast (c) govt. announcement on subsidy or new regulations?

(10) Have you access to meet with extension agents? (1) Yes (2) No

If yes, the, how many times in a month, please specify.

Section Two: Information about risk perception

(11) What is your opinion on major risk sources you are facing to continue agricultural farming in Bangladesh?

\begin{tabular}{|c|c|c|c|c|c|}
\hline Market risk & Very High & High & Medium & Low & Very Low \\
\hline \multicolumn{6}{|l|}{ 1. High Input price } \\
\hline \multicolumn{6}{|l|}{ 2. Low output price } \\
\hline \multicolumn{6}{|l|}{ 3. Long supply chain } \\
\hline \multicolumn{6}{|c|}{ 4. Change in govt. regulations } \\
\hline Climatic risk & Very High & High & Medium & Low & Very Low \\
\hline \multicolumn{6}{|l|}{ 1. Flood risk } \\
\hline \multicolumn{6}{|l|}{ 2. Heavy rain risk } \\
\hline \multicolumn{6}{|l|}{ 3. Heavy wind risk } \\
\hline \multicolumn{6}{|l|}{ 4. High precipitation } \\
\hline Biological risk & Very High & High & Medium & Low & Very Low \\
\hline \multicolumn{6}{|l|}{ 1. Rice blast risk } \\
\hline \multicolumn{6}{|l|}{ 2. Rice hoppers risk } \\
\hline \multicolumn{6}{|l|}{ 3. Weed infestation } \\
\hline 4. Rodent attacks & & & & & \\
\hline
\end{tabular}

Section Three: Basic information about respondents risk management strategy and adoption Decision

(12) Do you adopt any risk management strategy? (a) Yes (b) No

(13) Have you taken any agricultural credit? (a) Yes (b) No; If yes then,

(14) What is the value of all loans taken? BDT

(15) Why should you take the loan?

(a) Manage input cost (b) manage low output price (c) manage production loss (d) manage household expense

(16) From where do you repay the loan installments? (a) Farm income (b) off farm income (c) further borrowing

Section Four: Information about off farm Job

(17) Are you involved with off farm job? (a) Yes (b) No

(18) What is your present off farm job?

(a) tea stall (b) construction labor (c) rickshaw puller (d) trader (e) Carpenter (f) Craftsman (g) Dress maker

(h) Other, specify.

(c) rickshaw puller

(19) Income from off farm Job (please specify BDT/month)

Section Five: Information about Risk Attitude (If farmers show unresponsiveness to risk the result will be zero)

\begin{tabular}{|l|c|l|l|l|}
\hline Risk Attitude & Income range per month/BDT & Feel risk free & Feel risk & Neutral \\
\hline & Above 40000 & & & \\
\hline & $40000-38000$ & & & \\
\hline & $38000-36000$ & & & \\
\hline & $36000-34000$ & & & \\
\hline & $34000-32000$ & & & \\
\hline & $32000-30000$ & & & \\
\hline
\end{tabular}




\begin{tabular}{|l|c|l|l|l|}
\hline & $28000-26000$ & & & \\
\hline & $26000-24000$ & & & \\
\hline & $24000-22000$ & & & \\
\hline & $22000-20000$ & & & \\
\hline & $20000-18000$ & & & \\
\hline & $18000-16000$ & & & \\
\hline & $16000-14000$ & & & \\
\hline & $14000-12000$ & & & \\
\hline & $12000-10000$ & & & \\
\hline & Less than 10000 & & & \\
\hline
\end{tabular}

Thank you so much for you time and cooperation.

\section{References}

1. ALI M., ASHFAQ M., HASSAN S., ULLAH R. Assessing Indigenous Knowledge through Farmers' Perception and Adaptation to Climate Change in Pakistan. Polish J. Environ. Stud. 29 (1), 525, 2019.

2. KRESOVIĆ B., GAJIĆ B., TAPANAROVA A., DUGALIĆ G. How Irrigation Water Affects the Yield and Nutritional Quality of Maize (Zea mays L.) in a Temperate Climate. Polish J. Environ. Stud. 27 (3), 1123, 2018.

3. AKHTAR S., LI G., ULLAH R., NAZIR A., IQBAL M.A., RAZA M.H., IQBAL N., FAISAL M. Factors influencing hybrid maize farmers' risk attitudes and their perceptions in Punjab Province, Pakistan. J. Integr. Agric. 17 (6), 1454, 2018.

4. MCCARL B.A. Interpretations and Transformations of Aversion Coefficient: Implications for Scale for the PrattArrow Absolute Risk Generalized Stochastic Dominance: Comment. West. J. Agric. Econ. 12 (2), 228, 1987.

5. WORLD BANK. Managing Agricultural Production Risk Managing, Agriculture \& Rural Development Department, World Bank: Washington, D.C. 20433, US, 2015.

6. PARSHAD V.R., AHMAD N., CHOPRA G. Deterioration of poultry farm environment by commensal rodents and their control. Int. Biodeterior. 23 (1), 29, 1987.

7. HALKOS G., SKOULOUDIS A., MALESIOS C., EVANGELINOS K. Bouncing Back from Extreme Weather Events: Some Preliminary Findings on Resilience Barriers Facing Small and Medium-Sized Enterprises. Bus. Strateg. Environ. 27, 547, 2018.

8. SHAUKAT R., KHAN M.M., SHAHID M., SHOAIB M., KHAN T.A., ASLAM M.A. Quantitative Contribution of Climate Change and Land Use Change to Runoff in Tarbela Catchment, Pakistan. Polish J. Environ. Stud. 29 (5), $1,2020$.

9. HALKOS G., SKOULOUDIS A. Investigating resilience barriers of small and medium-sized enterprises to flash floods: a quantile regression of determining factors. Clim. Dev. 12 (1), 57, 2020.

10. ADNAN K., YING L., SARKER S., HAFEEZ M., RAZZAQ A., RAZA M. Adoption of Contract Farming and Precautionary Savings to Manage the Catastrophic Risk of Maize Farming: Evidence from Bangladesh. Sustainability 11, 29, 2018.
11. SARKER M.N.I., WU M., ALAM G.M., SHOUSE R. Administrative Resilience in the Face of Natural Disasters: Empirical Evidence from Bangladesh. Polish J. Environ. Stud. 29, 1825, 2020

12. NGUYEN T.P.L., SEDDAIU G., ROGGERO P.P. Declarative or procedural knowledge? Knowledge for enhancing farmers' mitigation and adaptation behaviour to climate change. J. Rural Stud. 67, 46, 2019.

13. ULLAH R., SHIVAKOTI G.P., ALI G. Factors effecting farmers' risk attitude and risk perceptions: The case of Khyber Pakhtunkhwa, Pakistan. Int. J. Disaster Risk Reduct. 13, 151, 2015.

14. AYINDE O.E. Effect of Socio-Economic Factors on Risk Behaviour of Farming Households: An Empirical Evidence of Small-Scale Crop Producers in Kwara State, Nigeria. Agric. J. 3 (6), 447, 2008.

15. AVEN T. Risk assessment and risk management: Review of recent advances on their foundation. Eur. J. Oper. Res. 253 (1), 1, 2016.

16. IQBAL M.A., PING Q., ABID M., KAZMI S.M.M., RIZWAN M. Assessing risk perceptions and attitude among cotton farmers: A case of Punjab province, Pakistan. Int. J. Disaster Risk Reduct. 16, 68, 2016.

17. SHIKUKU K.M., WINOWIECKI L., TWYMAN J., EITZINGER A., PEREZ J.G., MWONGERA C., LÄDERACH P. Smallholder farmers' attitudes and determinants of adaptation to climate risks in East Africa. Clim. Risk Manag. 16, 234, 2017.

18. ZAMASIYA B., NYIKAHADZOI K., MUKAMURI B.B. Factors influencing smallholder farmers' behavioural intention towards adaptation to climate change in transitional climatic zones: A case study of Hwedza District in Zimbabwe. J. Environ. Manage. 198, 233, 2017.

19. AYAL D.Y., FILHO W.L. Farmers' perceptions of climate variability and its adverse impacts on crop and livestock production in Ethiopia. J. Arid Environ. 140, 20, 2017,

20. ZHAI S., SONG G., QIN Y., YE X., LEIPNIK M. Climate change and Chinese farmers: Perceptions and determinants of adaptive strategies. J. Integr. Agric. 17 (4), 949, 2018.

21. BINICI T., KOÇ A.A., ZULAUF C.R. Risk Attitudes of Farmers in Terms of Risk Aversion: A Case Study of Lower Seyhan Plain Farmers in Adana Province, Turkey. Turkish J. Agric. For. 27, 305, 2018.

22. FAHAD S., WANG J., KHAN A.A., ULLAH A., ALI U., HOSSAIN M.S., KHAN S.U., HUONG N.T.L., YANG 
X., HU G., et al. Evaluation of farmers' attitude and perception toward production risk: Lessons from Khyber Pakhtunkhwa Province, Pakistan. Hum. Ecol. Risk Assess. An Int. J. 24 (6), 1710, 2018.

23. AZADI Y., YAZDANPANAH M., MAHMOUDI $H$. Understanding smallholder farmers' adaptation behaviors through climate change beliefs, risk perception, trust, and psychological distance: Evidence from wheat growers in Iran. J. Environ. Manage. 250, 109456, 2019.

24. SARKER M.N.I., WU M., ALAM G.M.M., SHOUSE R.C. Life in riverine islands in Bangladesh: Local adaptation strategies of climate vulnerable riverine island dwellers for livelihood resilience. Land Use Policy 94, 104574, 2020.

25. AHSAN D.A. Farmers' motivations, risk perceptions and risk management strategies in a developing economy: Bangladesh experience. J. Risk Res. 14 (3), 325, 2011.

26. RAHMAN A., JIANCHAO L., ADNAN K.M.M., ISLAM M.D., IL ZHAO M., SARKER S.A. How indebted farmers perceive and address financial risk in environmentally degraded areas in Bangladesh. Environ. Sci. Pollut. Res. 27, 7439, 2020.

27. TANAKA B.T., CAMERER C.F., NGUYEN Q. Risk and Time Preferences: Linking Experimental and Household Survey Data from Vietnam. Am. Econ. Rev. 100, 557, 2010.

28. TANG L., ZHOU J., BOBOJONOV I., ZHANG Y., GLAUBEN T. Induce or reduce? The crowding-in effects of farmers' perceptions of climate risk on chemical use in China. Clim. Risk Manag. 20, 27, 2018.

29. VAN WINSEN F., DE MEY Y., LAUWERS L., VAN PASSEL S., VANCAUTEREN M., WAUTERS E. Determinants of risk behaviour: Effects of perceived risks and risk attitude on farmers adoption of risk management strategies. J. Risk Res. 19 (1), 56, 2016.

30. KUŹMIŃSKI Ł., SZAŁATA Ł., ZWOŹDZIAK J. Measuring Aquatic Environments as a Tool for Flood Risk Management in Terms of Climate Change Dynamics. Polish J. Environ. Stud. 27 (4), 1583, 2018.

31. IFRI Institut français des relations internationales: Annual Report 2015, Paris, France, 2015.

32. SAQIB S.E., AHMAD M.M., PANEZAI S., RANA I.A. An empirical assessment of farmers' risk attitudes in flood-prone areas of Pakistan. Int. J. Disaster Risk Reduct. 18, 107, 2016.

33. ASLAM A.Q., AHMAD S.R., AHMAD I., HUSSAIN Y., HUSSAIN M.S. Vulnerability and impact assessment of extreme climatic event: A case study of southern Punjab, Pakistan. Sci. Total Environ. 580, 468, 2017.

34. SHELLEY I.J., TAKAHASHI-NOSAKA M., KANONAKATA M. Rice Cultivation in Bangladesh: Present Scenario, Problems, and Prospects. J. Int. Coop. Agric. Dev. 14, 20, 2016,

35. YAMANE T. Statistics: An Introductory Analysis., Harper \& Row: New York, US, 1967, ISBN 0060473134.

36. AKHTAR S., LI G., NAZIR A., RAZZAQ A., ULLAH R., FAISAL M., NASEER M.A.U.R., RAZA M.H. Maize production under risk: The simultaneous adoption of off- farm income diversification and agricultural credit to manage risk. J. Integr. Agric. 18 (2), 460, 2019.

37. ULLAH R., SHIVAKOTI G.P., KAMRAN A., ZULFIQAR F. Farmers versus nature: managing disaster risks at farm level. Nat. Hazards 82 (3), 1931, 2016.

38. COOPER D.F., BOSNICH P., WALKER P., PURDY G. Project Risk Management Guidelines: Managing Risk with ISO 31000 and IEC 62198, 2014, ISBN 9781118820315.

39. OGURTSOV V.A., VAN ASSELDONK M.P.A.M., HUIRNE R.B.M. Assessing and modelling catastrophic risk perceptions and attitudes in agriculture: A review. NJAS - Wageningen J. Life Sci. 56, 39, 2008.

40. ASRAVOR R.K. Farmers' risk preference and the adoption of risk management strategies in Northern Ghana. J. Environ. Plan. Manag. 62 (5), 881, 2019.

41. HALKOS G., MATSIORI S. Environmental attitudes and preferences for coastal zone improvements. Econ. Anal. Policy 58, 153, 2018.

42. HITAYEZU P., WALE E., ORTMANN G. Assessing farmers' perceptions about climate change: A doublehurdle approach. Clim. Risk Manag. 17, 123, 2017.

43. ULLAH R., SHIVAKOTI G.P. Adoption of On-Farm and Off-Farm Diversification to Manage Agricultural Risks. Outlook Agric. 43 (4), 265, 2014.

44. SARKER M.N.I., WU M., ALAM G.M., SHOUSE R.C. Livelihood Vulnerability of Riverine-Island Dwellers in the Face of Natural Disasters in Bangladesh. Sustainability 11, 1623, 2019.

45. HALKOS G.E., TSIRIVIS A.S. Value-at-risk methodologies for effective energy portfolio risk management. Econ. Anal. Policy 62, 197, 2019.

46. ALAM G.M.M., ALAM K., MUSHTAQ S., FILHO W.L. How do climate change and associated hazards impact on the resilience of riparian rural communities in Bangladesh? Policy implications for livelihood development. Environ. Sci. Policy 84, 7, 2018.

47. KHAN I., LEI H., SHAH I.A., ALI I., KHAN I., MUHAMMAD I., HUO X., JAVED T. Farm households' risk perception, attitude and adaptation strategies in dealing with climate change: Promise and perils from rural Pakistan. Land use policy 91, 104395, 2020.

48. NGUYEN T.P.L., SEDDAIU G., VIRDIS S.G.P., TIDORE C., PASQUi M., ROGGERO P.P. Perceiving to learn or learning to perceive? Understanding farmers' perceptions and adaptation to climate uncertainties. Agric. Syst. 143, 205, 2016.

49. ALAM G.M.M., ALAM K., MUSHTAQ S., SARKER M.N.I., HOSSAIN M. Hazards, food insecurity and human displacement in rural riverine Bangladesh: Implications for policy. Int. J. Disaster Risk Reduct. 43, 101364, 2020.

50. SARKER M.N.I., WU M., ALAM G.M., SHOUSE R.C. Livelihood resilience of riverine island dwellers in the face of natural disasters: Empirical evidence from Bangladesh. Land use policy 95, 104599, 2020. 